\title{
An investigation on systematic history and distribution areas of tarek (Alburnus tarichi (Güldenstädt, 1814))
}

\author{
A. A. Atici ${ }^{a, c *}$ (D), M. Elp ${ }^{b}$ (i) and F. Sen ${ }^{a}$ (D) \\ ${ }^{a}$ Department of Basic Sciences, Faculty of Fisheries, Van Yuzuncu Yil University, 65080, Van, Turkey \\ ${ }^{b}$ Department of Aquaculture Science, Faculty of Fisheries, Kastamonu University, 37150, Kastamonu, Turkey \\ 'Tarek Application And Research Center, Van Yuzuncu Yil University, 65080, Van, Turkey \\ *e-mail: atamanaltug@yyu.edu.tr
}

Received: December 4, 2019 - Accepted: April 14, 2020 - Distributed: August 31, 2021

(With 2 figures)

\begin{abstract}
This study aimed to determine the distribution area of tarek (Alburnus tarichi (Güldenstädt, 1814)) and to define how it must be called according to the scientific name by evaluating its previous studies made by various systematisers and their reports on its distribution, and by comparing literature knowledge. The taxonomic characteristics of the collected samples were evaluated and several measurements and counts were taken on the samples; analfin origin 0-4 scales behind dorsal fin-base; 72-91 lateral line scales; $21-29$ gill rakers; 71/2-10 branched dorsal-fin rays and 10-121/2 branched anal-fin rays. Body and caudal peduncle was moderately compressed. Body was covered by overlapping scales. Tarek has five different populations in the Basin. They are Van, Erçek, Nazik and Aygır Lakes and Koçköprü Dam Lake populations. The main living area of the tarek population is Lake Van; however, between May and June, mature individuals of tarek enter to tributaries of Van Lake. Some of them are Karasu, Bendimahi, Deliçay, Zilan, Karmuç, Sapur, Yanıkçay, Gevaş, Engil, Kurubaş and Akköprü Streams. At the end of study, it was concluded that tarek should be called as Alburnus tarichi (Güldenstädt, 1814) and it is an endemic fish species distributed only in Van Lake Basin.
\end{abstract}

Keywords: Alburnus tarichi, Chalcalburnus tarichi, taxonomy, Van Lake Basin.

\section{Uma investigação sobre a história sistemática e as áreas de distribuição de tarek (Alburnus tarichi (Güldenstädt, 1814))}

\section{Resumo}

Este estudo teve como objetivo determinar a área de distribuição de tarek (Alburnus tarichi) (Güldenstädt, 1814) e definir como deve ser chamado de acordo com o nome científico, avaliando estudos anteriores feitos por vários sistematizadores e seus relatórios sobre sua distribuição, e comparando o conhecimento da literatura. As características taxonômicas das amostras coletadas foram avaliadas e várias medições e contagens foram realizadas nas amostras, como origem analfin 0-4 escalas atrás da base da barbatana dorsal; 72-91 escalas de linha lateral; 21-29 rakers branquiais; $7 \frac{1}{2}-10$ raios da nadadeira dorsal ramificada, e $10-12 \frac{1}{2}$ raios da nadadeira anal ramificados. Pedúnculo caudal e corporal foram moderadamente comprimidos. $\mathrm{O}$ corpo estava coberto por escamas sobrepostas. Tarek tem cinco populações diferentes na bacia estudada. São as populações dos lagos Van, Erçek, Nazik e Aygır, e Koçköprü barragem. A principal área de presença da população tarek é o Lago Van; no entanto, entre maio e junho, indivíduos maduros de tarek entram nos afluentes do lago Van. Alguns deles são os fluxos Karasu, Bendimahi, Deliçay, Zilan, Karmuç, Sapur, Yanıkçay, Gevaş, Engil, Kurubaş e Akköprü. No final do estudo, concluiu-se que tarek deveria ser chamado Alburnus tarichi (Güldenstädt, 1814) e que é uma espécie de peixe endêmica distribuída apenas na Bacia do Lago Van.

Palavras-chave: Alburnus tarichi, Chalcalburnus tarichi, taxonomia, Bacia do Lago Van.

\section{Introduction}

First systematic classification of tarek was at the study of Pallas, Zoographia Rosso Asiatica first published in 1814 (Pallas, 1814). In subsequent years, its taxonomic characters were examined by Gunther, Deyrolle, Sauvage, Battalgil, Kosswig-Battalgil, Ladiges and Kuru (Geldiay and Balik, 2009). The name of the species remains valid as tarichi as in the first literature. Cetinkaya (1999) reported that this naming was an Arabic originated word associated with "history" for Lake Van in Futuh-ul Buldan (El Belazuri, 1987). Although this word means "salted and stored small fish" in Arabic, it may be derived from Greek word "tarichos" referring salted fish or processed salted fish (Cetinkaya, 2000). 
The initial distribution area of tarek was given as Gökçe Lake (Sevan) by Pallas (1814), however subsequent studies, only Van Lake has been reported as distribution area. Kuru (1975) recorded Başkale (Çı̆gli) Stream, the tributary of the Tigris River as the distribution area beside Van Lake Basin.

Evaluation of living organism in the ecosystem is primarily important for the protection of nature (Periotto and Tundisi, 2017). Maximum length values of tarek vary significantly depending on its habitat. Elp et al. (2014) reported that the biggest individuals have been lived in Erçek Lake introduced from Van Lake. The maximum fork length caught from Erçek Lake was $35 \mathrm{~cm}$. However, Van Lake and surrounding streams flowing to the lake constitute the basic distribution area of tarek. The largest individual caught from Van Lake was recorded as $22.5 \mathrm{~cm}$ fork length (Elp and Cetinkaya, 2006). In Nazik Lake and Koçköprü Dam Lake, maximum fork length of tarek does not exceed 20 cm (Kocabas, 1999; Elp, 2002).

Aquatic organisms unpredictably resistant to hydrological variations (Figueiredo et al., 2019). Tarek is an anadromous fish. While it migrates from the salty-alkaline waters of Van and Erçek Lakes to freshwater streams for reproduction, but it is showed in shallow waters of Nazik Lake, a freshwater source (Kocabas, 1999; Ekici and Duyar, 2005). In Koçköprü Dam Lake, they migrate from dam lake to the tributary (from a freshwater to other freshwater) (Elp, 2002). Tarek has different five populations in the Basin; they are Van, Erçek, Nazik, Aygır Lakes and Koçköprü Dam Lake (Sen et al., 1999, 2014; Elp and Sen, 2006; Elp et al., 2014, 2016).

\section{Material and Methods}

\subsection{Study area and sampling}

The study area consisted of the Van Lake Basin and Başkale (Çı̆̆li) Stream, a tributary of the Tigris River, where the tarek has been reported by Kuru (1975). Some samples were collection materials which were used at the Elp et al. (2013). In addition, other samples were collected from Başkale Stream and Van Lake Basin with the permission of the local ethic committee (approval date: 25.06.2015 and decision number: 2015/08). Electroshock method was used to reduce the selectivity to minimum in sampling.

\subsection{Measurements and counts}

Study material consists of Alburnus tarichi. In order to determine distribution area of tarek, the samplings were done in Van Lake and Başkale Stream Basins. The taxonomic characteristics of the collected samples were evaluated and several measurements and counts were taken on the samples at laboratories of the Fisheries Faculty, Van Yuzuncu Yil University, Turkey.

Measurements and counts were taken according to Kottelat and Freyhof(2007). Standard length was measured as the distance measured from the nose tip to the end of hypural complex. Caudal peduncle was measured as the distance from the end of the anal fin to the end of the hypural complex. The number of the scales on the lateral line was counted from the first perforated scale on the upper edge of operculum to the scale on the end of the hypural complex, and those on the tail fin are expressed as "+". Gill rakers were counted through the first gill arch. When the last two branched rays at dorsal and anal fins connected to a single pterygiophore it was recorded as " $1 \frac{1}{2}$ ". The origin of anal fin was determined based on the location of the first anal fin rays and how many scales there were behind the dorsal fin base.

\subsection{Diagnosis}

Alburnus tarichi (Figure 1) is distinguished from other species of Alburnus in East Anatolia by the combination of: head obtuse; anal fin origin 0-4 scales behind dorsal fin-base; 72-91 lateral line scales; 21-29 gill rakers; No or very faint lateral line in life; $7 \frac{1}{2}-10$ branched dorsal-fin rays and $10-12 \frac{1}{2}$ branched anal-fin rays; Ventral keel exposed for 9-20 scales in front of anus (Elp et al., 2013).

\subsection{Description}

Body and caudal peduncle was moderately compressed; Head profile was slightly concave; back was not humped behind head; mouth was slightly superior; lower jaw was slightly projecting beyond tip of upper jaw; pelvic fin origin in front of dorsal fin origin; caudal fin forked, lobes rounded; pelvic fins were not reached anus. Body was covered by overlapping scales. Lateral line was complete, reaching caudal fin base. Pharyngeal teeth are in two rows, 2.5-5.2 (Elp et al., 2013).

\subsection{Colour}

Body colour is metallic grey, back darker, ventral whitish. Free margins of lateral scales are black, crescent-shaped mark. Back scales and lateral head have scattered minute black spots (Elp et al., 2013).

\section{Results}

In the samplings of this and other studies, it was observed that tarek has been distributed only in Van Lake Basin. Tarek has five different populations in the Basin. They are Van, Erçek, Nazik and Aygır Lakes and Koçköprü Dam Lake populations (Figure 2). The main living area of the tarek population is Lake Van; however, between May and June, mature individuals of tarek enter to tributaries of Lake Van. Some of them are Karasu, Bendimahi, Deliçay, Zilan, Karmuç, Sapur, Yanıkçay, Gevaş, Engil, Kurubaş and Akköprü Streams (Figure 2). Van and Erçek Lakes, with different tarek populations, have alkaline and salty water, whereas Nazik and Aygır Lakes have completely

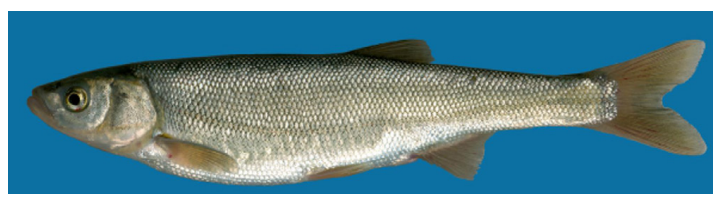

Figure 1. Alburnus tarichi; YYU-ZF 2007-23, 155 mm SL; Van prov.: Karmuç Stream (From Elp et al., 2013). 


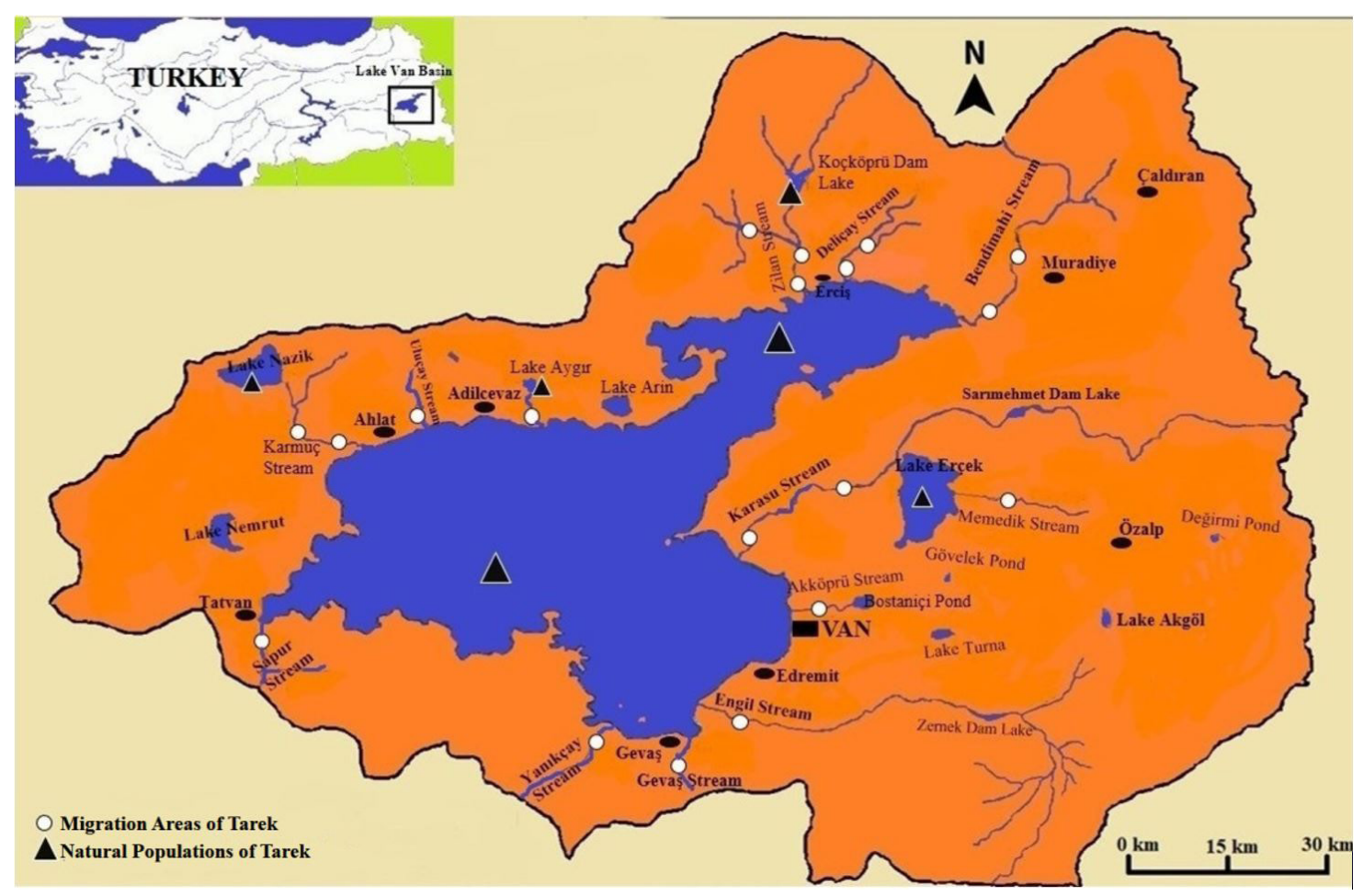

Figure 2. The distribution areas of tarek (Alburnus tarichi).

fresh water. Tarek migrates to tributaries of Van and Erçek Lakes for reproduction. However in Aygir and Nazik Lakes, they do not migrate for reproduction to another water sources. Tarek spawns in shallow coastal areas in these lakes (Elp et al., 2014; Sen et al., 2019).

Koçköprü Dam Lake was constructed on Zilan Stream (Erciş, Van, Turkey) in 1992, and population of tarek in Van Lake had separated from the other water sources. A new population of tarek has formed after the dam constructed. It has been observed that population of tarek in Koçköprü Dam Lake enters to the Zilan, Ilıca, Kömürcü and Kündük Streams between May and August (Elp et al., 2006).

Tarek has been introduced to Erçek Lake from population of Van Lake in 1980s and different population took place from the other water sources. Individuals of this population are larger than the others. Mature tareks of this population go in to Memedik Stream and other small water sources for reproduction between May and June (Elp and Sen, 2006).

Apart from these populations, no other population was found in other water sources in the Van Lake Basin, except during reproduction period.

The samplings were made in Başkale (Çı̆̆l1-Zapbaşı) Stream that located in Tigris River Basin in different periods with electroshock method because of to be reported by Kuru (1975), and there was no individuals of Alburnus genus.

\section{Discussion}

Alburnus is a genus of Cyprinidae family distributed in Europe and Asia Minor. The distinguishing characters of Alburnus tarichi are shown in a recent study as follows: total lateral line scales number 70-90, gill raker number 21-29, anal fin origin 3-4 scales behind the dorsal fin, anal fin branched rays number 10-11 1/2, scattered black spots located on scales (Elp et al., 2013). Individuals carrying these characters have been recognized as tarek.

First systematic records relating tarek were in Zoographi Rosso Asiatica written as 3 volumes by Pallas between 1811-1814 and in this book, tarek was called as Cyprinus tarichi. In binominal nomenclature, it was defined as Alburnus tarichi (Pallas, 1811). However, information on tarek was located in Volume 3 published in 1814. Moreover, this information does not belong to Pallas. In that regard, the information was given at the beginning of that section and it was recorded that its definition was done by Güldenstädt (Pallas, 1814). Since its first description, tarek has been evaluated in different genera of Cyprinidae family (Geldiay and Balik, 2009). Referring to, only in recent systematic studies, it has been reported in the genus Alburnus (Elp et al., 2013, 2014). Belong to this information; it should be named Alburnus tarichi (Güldenstädt, 1814) according to the binominal naming. After these reporting, Alburnus tarichi has been begun to use in some studies (Cicek et al., 2015; Kaptaner, 2015; Oğuz, 2015; Sen et al., 2015; Kaptaner et al., 2016; Arihan et al., 2017; Caf et al., 2018).

Information about the distribution of tarek has been also given by various researchers. The first information has located in Volume 3 of Zoographi Rosso Asiatica by Güldenstädt. It was indicated that the tarek distributed in Gökçe Lake (Sevan) (Pallas, 1814). However, there is no 
living species of the genus Alburnus at that lake. In addition, the presence of tarek is not mentioned in "study of fish and fisheries in Lake Sevan" (Savvaitova and Petr, 1999).

This wrong knowledge was noticed by Berg and it was noted that location information by place Güldenstädt was mistake (Berg, 1949) and he reported that samples of Güldenstädt belonged to Van Lake. In subsequent years, the tarek has also been reported from Lake Van Basin.

Tarek introduced to Burdur Lake (Turkey) in 1966 and Erçek Lake in 1989. Introducing to both lakes were successful, however it has been reported that economic production was not at the predicted level because of waste waters discharged into Burdur Lake. Today, there is no tarek in Burdur Lake (Aksiray, 1982; Balik and Ustaoglu, 2006; Sen et al., 2015).

Kuru (1975) reported that Başkale (Çığl1) Stream, one of the upper branches of Tigris River Basin, was a distribution area of the tarek beside Van Lake Basin. In the samplings of the present study and other studies on Çı̆̆lı Stream (Sen et al., 2014; Sen and Kara, 2016), tarek could not be caught. Samples were taken twelve times at the villages Atllar and Albayrak around the stream and its tributaries. In these samples, there were individuals belonging to the genus Capoeta, Barbus and Turchinemachilus, but there was not caught individual belonging to the genus Alburnus. During face to face interview, these issues were asked to Kuru, he said that there might be a labelling mistake in the recordings of Başkale Stream.

As a result, based on the given information above, it can be said that the tarek, Alburnus tarichi (Güldenstädt, 1814), is an endemic species and only widespread in Van Lake Basin. In addition today, there are still occasionally wrong naming for tarek as Chalcalburnus tarichi (Pallas, 1811) (Kankaya et al., 2012, 2015; Kaptaner and Kankaya, 2013; Oğuz, 2013; Kankaya and Kaptaner, 2014; Kaptaner et al., 2014; Oğuz and Yeltekin, 2014). This wrong nomenclature should be corrected as Alburnus tarichi (Güldenstädt, 1814).

\section{Acknowledgements}

We thank for supporting this project (Project no: 2006-ZF-YTR 12) to the Head of Scientific Research Project of Van Yuzuncu Yil University (BAPB).

\section{References}

AKŞIRAY, F., 1982. Die umweltfaktoren, die verbreitung und endwicklung Von Chalcalburnus tarichi (Pallas, 1811) (Pisces: Cyprinidae) in Burdur-See Begrenzen. Water Research, vol. 16, no. 7, pp. 1107-1112. http://dx.doi.org/10.1016/0043-1354(82)90126-9.

ARIHAN, O., KAPTANER, B. and KANKAYA, E., 2017. Erythrocyte fragility in pearl mullet (Alburnus tarichi Guldenstadt, 1814) during migration from highly alkaline water to freshwater. Fresenius Environmental Bulletin, vol. 26, no. 3, pp. 2325-2329.

BALIK, S. and USTAOGLU, R., 2006. Fishing studies and results carried out in Lakes, Ponds and Dam Lakes of Turkey. In: Proceedings of the Fisheries and Reservoir Management Symposium, 7-9 February 2006, Antalya, Turkey. Turkey: Akudemi, 2006, pp. 1-10.
BERG, L.S., 1949. Freshwater fishes of the USSR and adjacent countries. Moscow: Academy of Sciences of the USSR.

CAF, F., KOPRUCU, S., ALGUL, S., KOYUN, M. and ATICI, A.A., 2018. The correlation between the differences in NUCB2/ Nesfatin (NES) peptide levels and body weight, length and gender in Alburnus tarichi. Turkish Journal of Fisheries and Aquatic Sciences, vol. 18, no. 1, pp. 127-130. http://dx.doi. org/10.4194/1303-2712-v18_1_14.

CETINKAYA, O., 1999. Culture coming from water: Past and present of water resources and fishing in Ahlat. In: Proceedings of the IX Ahlat Culture Week Symposium, 22-24 October 1999, Bitlis, Turkey. Turkey: Akudemi, pp. 1-9.

CETINKAYA, O. 2000. Studies on the natural and fishery history of Eastern Anatolia water resources. In: Proceedings of the $I V$ Eastern Anatolia Fisheries Symposium, 28-30 June 2000, Erzurum, Turkey. Turkey: Akudemi, pp. 403-422.

CICEK, E., BIRECIKLIGIL, S.S. and FRICKE, R., 2015. Freshwater fishes of Turkey: a revised and updated annotated checklist. Biharean Biologist, vol. 9, no. 2, pp. 141-157.

EKICI, K. and DUYAR, H.A., 2005. Microbiological analysis of retail fresh Chalcalburnus tarichi caught from Van Lake in Turkey. Journal of Food Technology, vol. 3, no. 1, pp. 72-75.

EL-BELAZURI, A.B.Y., 1987. Futuhu'l Buldan. In: M. FAYDA, ed. Culture, conquest of countries. Ankara: Ministry of Tourism, $629 \mathrm{p}$.

ELP, M., 2002. A study on Capoeta capoeta (Guldensteadt, 1772) and Chalcalburnus tarichi (Pallas, 1811) population living in the Koçköprü Dam Lake (Van-Turkey). Istanbul: Istanbul University, 74 p. Thesis $\mathrm{PhD}$ in Istanbul.

ELP, M. and CETINKAYA, O., 2006. A study on some growth parameters of Chalcalburnus tarichi (Palas, 1811). Yuzuncu Yil University Journal of the Institute of Natural and Applied Sciences, vol. 11, pp. 42-47.

ELP, M. and SEN, F. 2006. The sample of fish vaccination studies in Van Lake Basin. In: Proceedings of the Fisheries and Reservoir Management Symposium, 7-9 February 2006, Antalya, Turkey. Turkey: Akudemi, 2006, pp. 337-342.

ELP, M., ATICI, A.A., SEN, F. and DUYAR, H.A., 2016. Distribution of fish species in the Van Lake Basin. Yuzuncu Yil University Journal of Agricultural Sciences, vol. 26, no. 4, pp. 563-568. http://dx.doi.org/10.29133/yyutbd.282808.

ELP, M., OZULUG, M., SEN, F. and FREYHOF, J., 2013. Validation of Alburnus timarensis from the Lake Van Basin, Eastern Anatolia (Teleostei: cyprinidae). Zoology in the Middle East, vol. 59, no. 3, pp. 235-244. http://dx.doi.org/10.1080/093 97140.2013.841430.

ELP, M., SEN, F. and ATICI, A.A., 2014. The distribution area of tarek (Alburnus tarichi (Guldenstaedtii, 1814)) in the Van Lake Basin, Turkey. Yuzuncu Yil University Journal of Agricultural Sciences, vol. 24, no. 3, pp. 228-232. http://dx.doi.org/10.29133/yyutbd.236277.

ELP, M., SEN, F. and CETINKAYA, O., 2006. The problems encountered by fish populations living in Lake Van basin and their possible solutions. E.U. Su Ürünleri Dergisi, vol. 23, no. 1/3, pp. 407-412.

FIGUEIREDO, R.S., VIANA, L.F., MORAES, D.P. and SÚAREZ, Y.R., 2019. Life-history traits of Farlowella hahni (Siluriformes, Loricariidae) in streams of the Ivinhema River Basin, Upper Paraná Basin. Brazilian Journal of Biology $=$ Revista Brasileira de Biologia, vol. 79, no. 2, pp. 286-293. http://dx.doi. org/10.1590/1519-6984.181073. PMid:30110082. 
GELDIAY, R. and BALIK, S., 2009. Turkey freshwater fish. 6th ed. Turkey: Ege University Press, 644 p.

KANKAYA, E. and KAPTANER, B., 2014. Increased apoptosis in the liver of Chalcalburnus tarichi exposed to sublethal concentrations of methyl parathion. Journal of Applied Biological Sciences, vol. 8, no. 1, pp. 45-48.

KANKAYA, E., ARSLAN, O.C., PARLAK, H. and UNAL, G., 2012. Induction of micronuclei in Chalcalburnus tarichi (Pallas, 1811) exposed to sub-lethal concentrations of methyl parathion. Fresenius Environmental Bulletin, vol. 21, no. 6, pp. 1417-1421.

KANKAYA, E., KAPTANER, B., DOGAN, A. and CELIK, I., 2015. Toxicity of bisphenol a during the early life stages of Chalcalburnus tarichi (Pallas, 1811). Fresenius Environmental Bulletin, vol. 24, pp. 977-985.

KAPTANER, B. and KANKAYA, E., 2013. Analysis of germ cell proliferation, apoptosis, and androgenesis in the Lake Van fish (Chalcalburnus tarichi) during testicular development. Fish Physiology and Biochemistry, vol. 39, no. 6, pp. 1665-1679. http://dx.doi.org/10.1007/s10695-013-9818-2. PMid:23756825.

KAPTANER, B., 2015. Relation between increased oxidative stress and histological abnormalities in the ovaries of Alburnus tarichi in Lake Van, Turkey. Environmental Monitoring and Assessment, vol. 187, no. 11, pp. 702. http://dx.doi.org/10.1007/ s10661-015-4936-1. PMid:26497562.

KAPTANER, B., KANKAYA, E., DOGAN, A. and CELIK, I., 2014. Histopathology and oxidative stress in the liver of Chalcalburnus tarichi living in lake Van, Turkey. Life Science Journal, vol. 11, no. 8, pp. 66-77.

KAPTANER, B., KANKAYA, E., DOGAN, A. and DURMUS, A., 2016. Alterations in histology and antioxidant defense system in the testes of the lake Van fish (Alburnus tarichi Güldenstädt, 1814). Environmental Monitoring and Assessment, vol. 188, no. 8, pp. 474. http://dx.doi.org/10.1007/s10661-016-5476-z. PMid:27435621.

KOCABAS, M., 1999. Studies on the structure, growth, reproduction and foods of the Chalcalbumus tarichi population in the Lake Nazik (Ahlat-Bitlis, Turkey). Van, Turkey: Yuzuncu Yil University, 54 p. Thesis MsC in Van.

KOTTELAT, M. and FREYHOF, J., 2007. Handbook of European freshwater fishes. Berlin: Kottelat, Cornol and Freyhof, 646 p.

KURU, M., 1975. Systematic and zoogeographic examination of pisces living in freshwater waters of Tigris-Firat, Kura-Aras, Van Lake and Black Sea Basin. Erzurum, Turkey: Ataturk University, 182 p. Thesis in Erzurum.
OĞUZ,A.R., 2013. Environmental regulation of mitochondria-rich cells in Chalcalburnus tarichi (Pallas, 1811) during reproductive migration. The Journal of Membrane Biology, vol. 246, no. 3, pp. 183188. http://dx.doi.org/10.1007/s00232-012-9518-3. PMid:23124947.

OĞUZ, A.R., 2015. A histological study of the kidney structure of Van Fish (Alburnus tarichi) acclimated to highly alkaline water and freshwater. Marine and Freshwater Behaviour and Physiology, vol. 48, no. 2, pp. 135-144. http://dx.doi.org/10.108 0/10236244.2015.1004838.

OĞUZ, A.R. and YELTEKIN, A., 2014. Metal levels in the liver, muscle, gill, intestine, and gonad of Lake Van Fish (Chalcalburnus tarichi) with Abnormal Gonad. Biological Trace Element Research, vol. 159, no. 1-3, pp. 219-223. http://dx.doi.org/10.1007/s12011014-9980-0. PMid:24763711.

PALLAS, P., 1814. Zoographia Rosso Asiatica. Petropoli: Academiae Scientiarum Impress, 660 p. no. 3.

PERIOTTO, N.A. and TUNDISI, J.G., 2017. A characterization of ecosystem services, drivers and values of two watersheds in São Paulo State, Brazil. Brazilian Journal of Biology = Revista Brasileira de Biologia, vol. 78, no. 3, pp. 397-407. http://dx.doi. org/10.1590/1519-6984.166333. PMid:29166428.

SAVVAITOVA, K.A. and PETR, T., 1999. Fish and fisheries In Lake Sevan, Armenia, and in some other high altitude lakes of Caucasus. Rome: FAO. FAO Fisheries Technical Paper, no. 385.

SEN, F. and KARA, O., 2016. Population structure, growth and reproduction properties of barbel (Barbus plebejus Bonaparte, 1832) living in Çığlı stream, Van, Turkey. Iranian Journal of Fisheries Science, vol. 15, no. 2, pp. 827-838.

SEN, F., ATICI, A.A. and ELP, M., 2019. Endemic fish species of Van Lake Basin. YYU (Van Yüzüncü Yıl Üniversitesi). Yuzuncu Yil University Journal of Agricultural Sciences, vol. 28, pp. 63-70.

SEN, F., CETINKAYA, O. and ELP, M. 1999. A study on the Capoeta capoeta (Guldenstaedt, 1773) population living in Lake Nazik (Ahlat-Bitlis, Turkey). In: Proceedings of the X National Aquaculture Symposium, 22-24 September 1999, Adana, Turkey. Turkey: Akudemi, pp. 465-475.

SEN, F., ELP, M. and KARA, O., 2014. Population structure, growth and reproduction properties of Capoeta capoeta (Guldenstaedt, 1772) living in Cigli (Zapbasi) stream, Van, Turkey. Journal of Animal and Veterinary Advances, vol. 13, no. 3, pp. 119-122. http://dx.doi.org/10.36478/javaa.2014.119.122.

SEN, F., PARUG, S.S. and ELP, M., 2015. Projections on past, present and future of tarek (Alburnus tarichi, Güldenstädt, 1814). Yuzuncu Yil University Journal of Agricultural Sciences, vol. 25, no. 3, pp. 347-356. http://dx.doi.org/10.29133/yyutbd.236420. 